\title{
E-Commerce Use on Micro, Small and Medium Enterprises (Case study: SMEs at Padang City of Indonesia)
}

\author{
Sepris Yonaldi ${ }^{1}$, Hafrizal Okta Ade Putra ${ }^{2}$, Muhamad Fauzan ${ }^{3}$ \\ ${ }^{1}$ Department of Management , Faculty of Economics , Tamansiswa University, Padang \\ ${ }^{2}$ Department of Management, Faculty of Economics, Tamansiswa University, Padang \\ ${ }^{3}$ Department of Management, Faculty of Economics, Tamansiswa University, Padang \\ (cc) $\mathrm{EY}$
}

\begin{abstract}
This study aims to reveal the influence of the ability to use computer (Computer self-efficacy) perpetrators of small and medium enterprises (SMEs) at Padang city to perceptions of expediency (perceived usefulness) in the adoption of e-commerce. This research method using explanatory approach with survey technique. This study assigned 35 samples, namely SMEs in Padang city that uses E-Commerce in its business. Partial Least Square (PLS) is used as a tool analyst is, where the PLS was developed by wold as a method to estimate the path latent constructs a model using multiple indicators. The results of this study are: Computer Self Efficacy has a positive effect on Perceived Use fullness in the adoption of e-commerce. This is indicated by a significant and positive relationship between the two variables.
\end{abstract}

Keyword - Computer Self Efficacy; E-Commerce; Perceived Usefulness; Padang City.

\section{INTRODUCTION}

Reality today E-commerce not only as a supporting instrument, but its existence is transformed into a lifestyle (e-lifestyle) in buying and selling transactions without any limitations of space and time. According Vermaat (2007: 83) in (Lestari, Ginting, \& Zaini, 2017) E-Commerce is a business transaction that occurs in electronic networks such as the Internet.

With the availability of infrastructure and devices in accessing internet network, then all business and society as consumer will be able to use E-commerce as a tool or media to conduct sale and purchase transactions with wider meaning. The power of digital technology in E-commerce activities will facilitate manufacturers in conducting business activities, such as promotions, buying and selling using e-money, providing services faster, easier to get information about consumer behavior, and other things. Likewise on the contrary consumers will be more facilitated in collecting information about the products needed, consumers do not need much time and travel long distances to conduct transaction, as well as a very fast service process.

According to data, total internet growth worldwide from 2000 to 2014 reached $741 \%$. While in Indonesia internet users reached 132.7 million users of the total population 257,912,349 in June 2016 (APJII, 2017). From this data can be concluded that about $51.45 \%$ of the population of Indonesia can be a target market for business actors in Indonesia, and more than $43 \%$ of the world's population can be a target market.

(West Sumatra, 2017) in 2017 showed growth in the number of micro small and medium business in the city of Padang as many as 2,953 SMEs. Total there are as many as 81.182 SMEs in the city of Padang in 2017, seen that the growth of SMEs in the city of Padang increased marked more and more SMEs business actors that grow in every District in the city of Padang on Her every year.

Ecommerce will facilitate the perpetrators of SMEs in applying the main principles of business that is effective and 
efficient. (Irmawati, 2011;28) The existing process in $E$ commerce is as follows:

a. Electronic presentation (website creation) for products and services.

b. Instant reservation and availability of invoices.

c. Automatically automate customer accounts (both account numbers and Credit Card numbers).

d. Payments made directly (online) and handling transactions.

(Nasution, 2004; 30) Thomson et.al (1991)suggests the importance of behavioral aspects in the application of PC usage. Tompson .et.al (1991) states that attitude factor is an aspect that influences individual attitude, where sap is composed of:

a) Cognitive dimension (cognitive)

b) Affection dimension (affective) c) Dimensions relating to behavior (behavioral components).

Technology Acceptance Model (TAM) needed to analyze and describe computer user behavior (computer usage behavior ). TAM is intended only for behavioral use of computer technology (Davis et.al,, 1986). The main purpose of the real TAM is to provide a basic measure of the impact of external factors on internal beliefs, attitude, and intention (Lucyana, 2010; 31)

According to (Saadé, 2009: 33) Self-efficacy was initially defined as an individual's belief about his/ her ability to successfully execute a behavior required to produce a desired outcome. Computer self-efficacy focuses on a person's beliefs, that he/ she is capable of using computer equipment in doing activities related to its business operations.

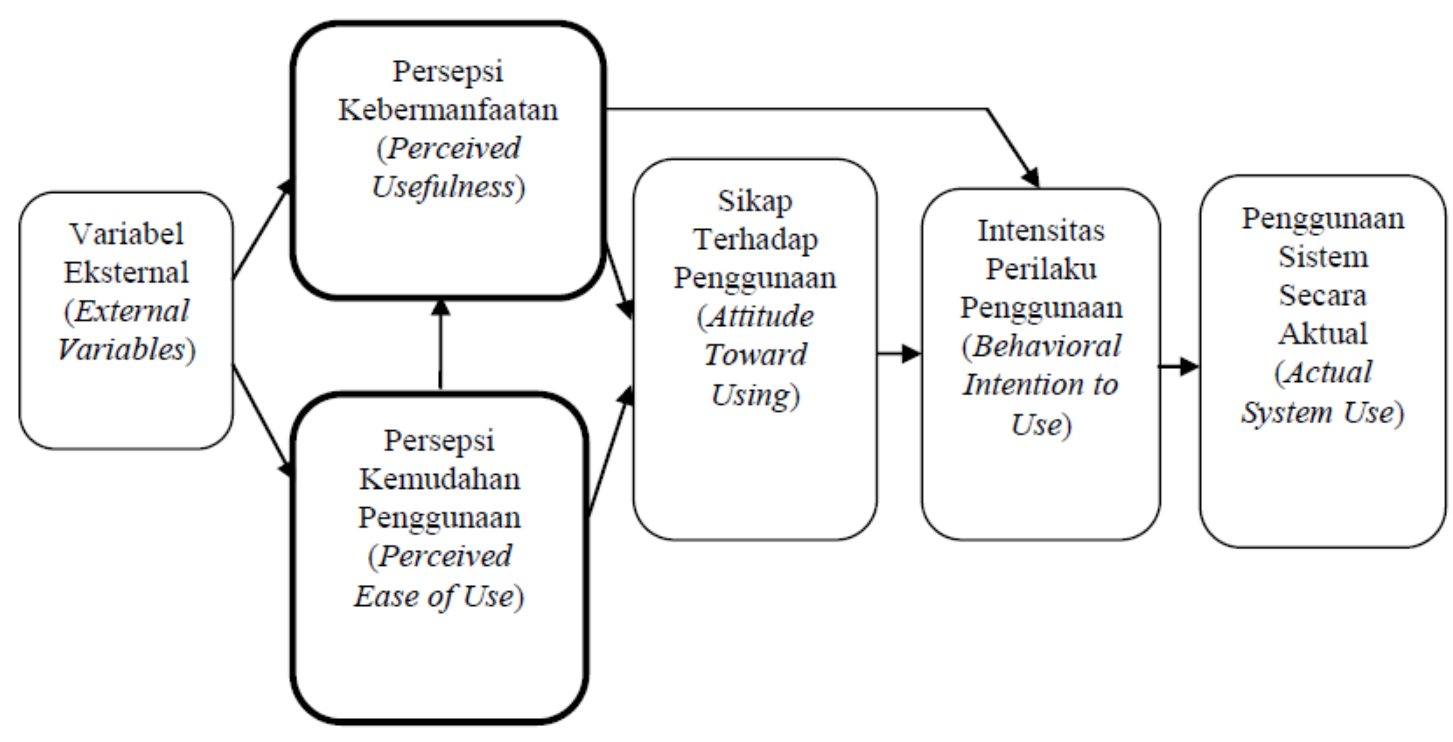

Figure 1. Technology Acceptance Model (Davis, 1989)

(Fatmawati, 2015, 35) In TAM there are 5 constructs (Davis et al , 1986), namely:

1. Perceived ease of use

To measure the level of trust throughout an about using technology in facilitating operationalize their business.

2. Perceived usefulness

To measure the level of trust throughout a that utilizing technology will improve the performance of its business.
3. Attitude toward using

Evaluation of the user about his interest in using technology.

4. Behavioral intention to use

Reveals how Interest (desire) in behaving using technology

5. Actual technology usage 
The extent to which the use of technology in business operations in terms of the use of time and frequency of use of these technologies.

Perceived usefulness is defined as the ability of individuals to believe, that utilizing digital technology can increase productivity work. A review of previous research revealed that utility construct perception (perceived usefulness) positive and significant impact on the use of information technology systems (eg, Davis, 1989; Chau, 1996; Igbaria et al., 1997; Sun, 2003).

This study aims to reveal the influence of the ability of using computers (Computer self-efficacy) small and medium enterprises (SMEs) at Padang to Perceived usefulness in the adoption of e-commerce.

\section{RESEARCH METHODS}

This research will be conducted by quantitative method, as an explanatory research in a field survey research. Sample this study was 35 SMEs are already doing business with the use of E-Commerce in the city of Padang. The sampling technique used in this research is non probability sampling with convenience sampling technique.

Primary data used in this study comes from survey results by distributing questionnaires to 35 actors of SMEs in the city of Padang. To prove the hypothesis and to know the purpose of this research, Partial Least Square (PLS) is used as an Analysis tool, PLS is developed by Wold as a method of estimating path model using latent multiple indicator construct.

\section{III.RESULT AND DISCUSSION}

Generally there Computer Self Efficacy ( CSE ) of SMEs in Padang city is included in very good category because the average value of Total Achievement of Respondents (TCR) for Computer Self Efficiency (CSE ) is $91.5 \%$ which is between $89.7 \%$ to $93.7 \%$. From this research it can be seen that the lowest respondent's total (TCR) is a questionnaire statement "I need to use e-commerce even though no one has used transactions through e-commerce. "With the value of $89.7 \%$ with good category. Also known to be the highest TCR is I use e-commerce because it has a reference as a reference in its use. "With a TCR value of $93.7 \%$ with very good category.

Perceived Usefulness) ( PU) SMEs in the city of $\mathrm{P}$ is included in the category very well because the average value of Total Achievement of Respondents (TCR) for Perceived Usefulness ( PU ) is $92.1 \%$ that is between $89.1 \%$ to $97.1 \%$. From the results of the research questionnaire can be in the know that the lowest TCR is a statement questionnaire with e-commerce product marketing more effective. With a value of $89.1 \%$ (good category). Besides, it is known that the highest TCR is ecommerce can help now consumers taste and interest, with TCR value of $97.1 \%$ (very good category).

Hypothesis testing is done by looking at the output path coefficient of the resampling bootstrap result can be seen in the following table:

Table Output Path Coefficient

\begin{tabular}{|c|c|c|c|c|}
\hline TAM & Original Sample $(\mathrm{O})$ & T Statistics $(\mathrm{O} / \mathrm{STDEV})$ & T table & Information \\
\hline CSE -> PU & 0.132 & 2.212 & 1,691 & Ha Accepted \\
\hline
\end{tabular}

Source: SmartPLS Data Processing Result version 3.7 for Windows, Year 2018

Based on the hypothesis testing submitted can be accepted. Output path coefficients shows that the statistical t value for the Computer Self Efficacy (CSE) construct of the PU construct above 1,691 is equal to 2,212 so that the influence given by the CSE on perceived usefulness (PU) constructs proved to be significant. 


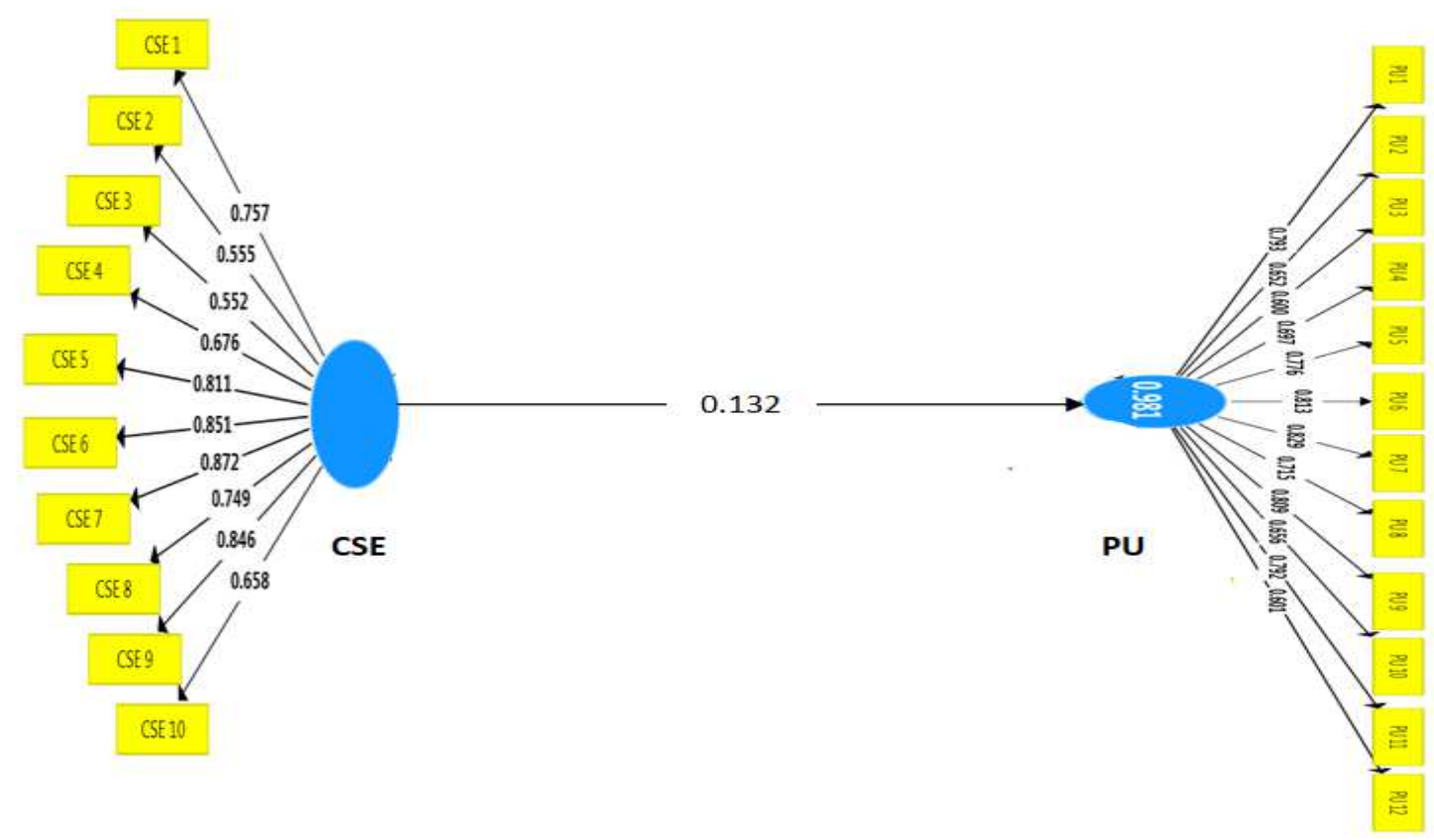

Figure 2. Loading Factor Model Execution

Source: SmartPLS Data Processing Result version 3.7 for Windows, Year 2018

The coefficient value of CSE latent variable on output path coefficients is 0.132 which means there is a positive influence of $13 \%$ to PU construct. The higher the confidence of using the computer (e-commerce) to support business activities, the higher the perception of e-commerce system usability in SMEs. It can logically be perceived if SMEs who has an understanding of the computer will use ecommerce as a supporter of its business activities will surely be used / adopted.

\section{CONCLuSion}

The results of this study concluded that the Computer self Efficacy positive effect on perceived usefulness in the adoption of e-commerce to support the business activities of SMEs in Padang City, so the hypothesis is supported.

\section{REFERENCES}

[1] APJII. (2017). Hasil Survei Penetrasi dan Perilaku Pengguna Internet Indonesia 2017

[2] Lestari, L., Ginting, B., \& Zaini, O. K. (2017). Pengaruh E-Commerce Terhadap Volume Penjualan Pada Online
Shop Aneka Kemeja Pria Bekasi. Jurnal Online Mahasiswa (JOM) Bidang Manajemen, 1(1).

[3] Sumbar, A. (2017). Selama 2017, Sebanyak 2.953 UMKM Hadir di Padang.

[4] Irmawati, D. (2011). Pemanfaatan e-commerce dalam dunia bisnis. Jurnal Ilmiah Orasi Bisnis-ISSN, 2085, 1375.

[5] Nasution, F. N. (2004). Penggunaan teknologi informasi berdasarkan aspek perilaku (Behavioral aspect). USU digital library.

[6] Lucyanda, J. (2010). Pengujian Technology Acceptance Model (TAM) dan Theory Planned Behavior (TPB). JRAK (Jurnal Riset Akuntansi dan Komputerisasi Akuntansi), 1(2), 1-14.

[7] Saadé, R. G., \& Kira, D. (2009). Computer anxiety in elearning: The effect of computer self-efficacy. Journal of Information Technology Education: Research, 8, 177191.

[8] Fatmawati, E. (2015). Technology Acceptance Model (Tam) Untuk Menganalisis Penerimaan Terhadap Sistem Informasi Perpustakaan. Jurnal Iqra' Volume, 09(01). 